\title{
Halállományok védelmében tett nemzetközi egyezmények játékelméleti vizsgálata
}

\section{Examination of International Fisheries' Agreements with Game Theoretic Approaches}

\author{
O. SZENDREY1 ${ }^{1}$ A. KARCAGI-KOVÁTS² \\ ${ }^{1}$ Kaposvári Egyetem Gazdálkodás- és Szervezéstudományok Doktori Iskola, szendrey.orsi@gmail.com \\ ${ }^{2}$ Debreceni Egyetem Gazdaságtudományi Kar Környezetgazdaságtan Tanszék, karcagi- \\ kovats.andrea@econ.unideb.hu
}

\begin{abstract}
Absztrakt. Napjainkban a játékelmélet alkalmazása a természeti erőforrásokhoz kapcsolódó nemzetközi megállapodások és elosztási kérdések vizsgálata egyre szélesebb körben nyer teret. Cikkünkben - a téma EU szinten is felismert jelentőségéből kiindulva - ezen megállapodásokat és allokációs kérdéseket a nemzetközi, kizárólagos gazdasági területeken túlnyúló halászatok és halászati jogok (kvóták) esetében vizsgáljuk, áttekintve és összehasonlítva a témába elért legfontosabb játékelméleti kutatási eredményeket. A halászat, azon belül is a "túlhalászat" kérdésének elemzésére kiemelt figyelmet fordítva megvizsgáljuk, hogy a játékelmélet eszköztárát felhasználva felépithető-e olyan stabilitási követelményeknek is eleget tevő modell, amely alkalmazásával elkerülhető a közlegelők tragédiája, illetve figyelembe veszi a probléma jellegéből adódó externáliákat és az esetlegesen megjelenő potyautas jelenséget is. Az elemzéshez játékelmélet eszköztárára és a témában elért legjelentősebb tudományos eredményekre támaszkodunk, melyeket empirikus eredmények bemutatásával is alátámasztunk.
\end{abstract}

Abstract. Nowadays, the application of game theoretic approaches is becoming more and more popular in different types of resource management problems. Overfishing is a growing problem worldwide and well known from literature. Unfortunately the tragedy of commons could be observed in several empirical studies in the case of international fisheries. In our paper, we focus on the examination of international agreements related the fisheries' management (with special focus on the issues of overfishing) using game theoretic approaches. We review the history of fisheries' agreements and the main game theoretic results, well known from literature. We highlight the main types of games applied in the previous research studies and summarize the main results related to the outcome and the stability of the game. To this topic better understood, certain empirical examples are introduced as well.

\section{Bevezetés}

Napjainkban a játékelmélet alkalmazása a természeti erőforrásokhoz kapcsolódó nemzetközi megállapodások és elosztási kérdések vizsgálata egy szélesebb körben nyer teret. Cikkünkben - a téma EU szinten is felismert jelentőségéből kiindulva - ezen megállapodásokat és allokációs 
kérdéseket vizsgáljuk a nemzetközi, kizárólagos gazdasági területeken túlnyúló halászatok és halászati jogok (kvóták) esetében, valamint áttekintjük és összehasonlítjuk a témába elért legfontosabb játékelméleti kutatási eredményeket. A halászat, azon belül is a "túlhalászat” kérdésének elemzésére kiemelt figyelmet fordítva megvizsgáljuk, hogy a játékelmélet eszköztárát felhasználva felépíthető-e olyan - stabilitási követelményeknek is eleget tevő - modell, amely alkalmazásával elkerülhető a közlegelők tragédiája, illetve figyelembe veszi a probléma jellegéből adódó externáliákat és az esetlegesen megjelenő potyautas jelenséget is. Az elemzéshez a játékelmélet eszköztárára és a témában elért legjelentősebb tudományos eredményekre támaszkodunk, melyeket empirikus eredmények bemutatásával is alátámasztunk.

Napjainkban a halászathoz kapcsolódó fenntartható jogi, gazdasági, társadalmi és környezeti feltételek, keretrendszer és nemzetközi megállapodások kiemelt jelentőséggel bírnak a nemzetközi döntéshozatali folyamatokban. A világ kulcsfontosságú halászati területeinek, halállományainak megóvása, az illegális halászat visszaszorítása és nemzetközi ellenőrzés alá vonása így méltán képezi az Európai Unió kiemelt törekvéseinek részét, melyek megvalósítása részben nemzetközi halászati megállapodások megkötésén és betartatásán keresztül lehetséges. Mielőtt azonban rátérnénk a halászati megállapodások részletes vizsgálatára, áttekintjük mindazon eseményeket és mérföldköveket a nemzetközi halászat szabályozásában, melyek a jelenleg érvényben lévő keretrendszer kialakulásához vezettek.

A tengerekhez, és így a halállományokhoz való hozzáférés szabályozására tett első intézményesített törekvések a 17. századra nyúlnak vissza, egészen a Tengerek Szabadsága (Freedom of the Seas) doktrína elfogadásához. A doktrína a partmenti és nyíltvizek elhatárolását tűzte ki célul, mely szerint a nyíltvizek erőforrásai minden ország tulajdonát képezik, arra egyik ország sem jogosult önkényes igényt megfogalmazni. A 19. századig ez a doktrína elégséges szabályozásnak bizonyult, hiszen az óceánok halállományai kimeríthetetlennek látszottak, ugyanis a halászati technológia akkori fejlettségi szintje nem tette lehetővé a túlhalászatot.

1973 és 1982 között az ENSZ III. tengerjogi konferenciája (UN Third Conference on the Law of the Sea) az előzőekben említett nyitott kérdések megoldását az exkluzív gazdasági zónák (Exclusive Economic Zone - EEZ) kialakításával látta megvalósíthatónak. Az EEZ rendszer 200 tengeri mérföldön belül kizárólagos halászati jogot biztosított a part menti országnak. Az 1982. évi tengerjogi egyezmény ratifikálta a tengerjogi viták kötelező bírói rendezésének elvét, így jogi eszközökkel törekedett arra, hogy megakadályozza a tengerek és erőforrásaik kisajátítására és kizsákmányolására irányuló törekvéseket, valamint biztosítani akarta a tengerek szabadságát, és rögzítette a tengerparttal nem rendelkező országok halászathoz és tengerekhez kapcsolódó jogait is.

Érdemes kiemelni, hogy az Európai Unió érdekeltségével a mélytengeri halászat esetében és az EEZ-kre vonatkozóan több nemzetközi megállapodás jött létre, melyek szabályozzák a lobogó szerinti, illetve a part menti országok kötelezettségeit és felelősségeit, így kiemelt jelentőséggel bírnak a halállományok megőrzését és kezelését veszélyeztető illegális, illetve szabályozatlan halászat megfékezésében.

Az 1970-es évekre az volt tapasztalható, hogy számos nem EU-tagállam hozott létre 200 tengeri mérföldes EEZ-t. Ez, a rendszer fenntarthatósága miatt, szükségessé tette a felek között a két- és 
többoldalú halászati megállapodások megfogalmazását. Az ENSZ 1982-ben elfogadta a tengerjogi egyezményt (UNCLOS), és ezzel elismerte a part menti országok jogait a szomszédos vizekben kihalászott halak mennyiségének szabályozására vonatkozóan. Ezt követően az ENSZ 1995-ös halászati egyezménye megfogalmazta, hogy az EEZ-k között nagy mennyiségben vándorló halállományokat regionális szinten szükséges kezelni, melyekre a regionális halgazdasági szervezetek adta keretrendszer teremtette meg a lehetőséget. (Regional Fisheries Management Organisation - RFMO-k létrehozása pl. North Atlantic Fisheries Organization vagy Northeast Atlatic Fisheries Commission)

Az elfogadott egyezmény regionális halászati gazdálkodási szervezetek létrehozását szorgalmazta abból a célból, hogy ezek a szervezetek megkönnyítsék az országok között olyan együttműködések megvalósítását, melyek megóvják és kellően körültekintően kezelik a nyílt tengerek erőforrásait. Ennek eredményeként a távoli halászflottákkal (Distant Water Fishing States - DWFS-ek) rendelkező tagállamok nemzetközi megállapodásokon és egyezségeken keresztül férhetnek hozzá a halállományokhoz, mind a harmadik országok kizárólagos halászati övezeteiben, mind a regionális halászati gazdálkodási szervezetek hatáskörébe tartozó nyílt tengereken.

Összességében elmondható, hogy az EEZ és az RFMO-rendszer bevezetésével az halállományok kezelése erőforrás-menedzsment kérdéssé vált. A rendszer legfőbb kritikájának az tekinthető, hogy a nem RFMO tagok nyíltvízi halászati tevékenysége kívül esik a szabályozáson.

\section{Nemzetközi halászati megállapodások}

Ebben a fejezetben áttekintjük, hogy az Európai Unióban milyen, két vagy többoldalú, halászati egyezményeket kötöttek.

A kétoldalú halászati megállapodások lehetnek halászati partnerségi egyezmények, melyek a közös halászati politika reformjának és a fenntartható fejlődésről szóló johannesburgi csúcsnak a legfőbb eredményei. Ezen kölcsönösen előnyős megállapodások célja, hogy biztosítsa a felelős és fenntartható halászatot és a kapcsolódó termékek, illetve erőforrások értékének növelése érdekében partnerségi kapcsolatot alakítson ki harmadik országokkal.

A kétoldalú halászati megállapodások másik típusába sorolhatók a kölcsönös megállapodások. Ezek a megállapodások a halászati lehetőségek cseréjén alapulnak az EU és a harmadik országok között. Az ilyen módon megkötött megállapodások a halállományok együttes kezelését eredményezik. Az egységes csere követelményének megfelelően a csere tőkehal-egyenértékben meghatározott referencia értéken alapul.

A többoldalú egyezmények közül elsőként a regionális halászati gazdálkodási szervezetekkel köttetett megállapodásokat emeljük ki. Ezen egyezmények a regionális együttmúködés megerősítését célozzák mind a nyílt tengeri erőforrások, mind a vándorló halállományok megőrzésének és fenntartható kiaknázásának elősegítése céljából. Az egyezmények meghatározó célja továbbá az illegális és szabályozatlan halászat megakadályozása. A regionális halászati gazdálkodási szervezetek sok esetben tudományos alapon opcionális és kötelező érvényü ajánlásokat fogalmazhatnak meg az állományok védelme érdekében, melyek lehetnek kvóták, 
tiltott halászati időszakok vagy övezetek, illetve a halászfelszerelésekre vonatkozó korlátozások [1]. A többoldalú megállapodások másik csoportját alkotják a nemzetközi egyezmények, melyek célja tengerekhez kapcsolódó jogrendszer megteremtése és a vizek békés célú felhasználásának, erőforrásaik fenntarthatóságának és élőviláguk megőrzésének előmozdítása. Egyes, úgynevezett makroregionális együttműködések szintén kitérnek halászati, vízgazdálkodási kérdésekre is, ahogyan az a Balti-stratégia és a Duna-stratégia esetében is látható [2].

A fenntarthatóságot szolgáló többoldalú nemzetközi megállapodások előkészítésében, illetve azok betartásának ellenőrzésében az államokon túl jelentős szerepet játszhatnak a civil szféra szervezetei is [3].

\section{Játékelméleti kutatások}

A játékelmélet mint modellezési és elemzési keretrendszer, számos lehetőséget biztosít a nemzetközi halászati egyezmények vizsgálatára, így a nemzetközi irodalomban is számos kutatási eredmény érhető el a témában.

Az első kiemelkedő és máig számos kutatás alapját képező játékelméleti eredmény Munro 1979ben publikált cikkéhez köthető [4], mely rávilágít arra a tényre, hogy az exkluzív gazdasági zónák létrehozásával a halállományok kezelése az országok együttműködését és a probléma közös kezelését feltételezi. Tanulmányában Munro részleteiben vizsgálta az alkumegoldások alkalmazhatóságát, valamint a játékosok között fennálló aszimmetria hatását a játékra.

A játékelméleti kutatások alapját számos esetben két jól ismert modell képezi: a halállományok változását leíró, Gordon-Schaefer bioökonómiai modell [5,6], valamint a Clark és Munro eredményeihez köthető dinamikus modell [7,8].

A Gordon-Schaefer modellben a halállomány változása t idő alatt

$$
\frac{\mathrm{d} X}{\mathrm{~d} t}=G(X)-\sum_{i=1}^{n} H_{i}
$$

A halállomány növekedése az alábbi módon adott:

$$
G(X)=r X\left(1-\frac{X}{k}\right) .
$$

Az i-edik szereplő halászati tevékenységét jelölje $H_{i}$, melyre

$$
H_{i}=q E_{i} X \text {. }
$$

Az i-edik szereplő kifizetése ekkor:

$$
\pi_{i}=p H_{i}-c_{i} \cdot E_{i},
$$

ahol

- X: halállomány,

- $H_{i}$ : az i-edik játékos halászata,

- $E_{i}$ : halászatra fordított ereje (költség),

- $\quad N=\{1,2, \ldots, n\}$ a játékosok halmaza, 
- $\quad n$ : a halászó országok száma,

- $\quad r$ : a halállomány belső növekedési üteme,

- $k$ : az ökoszisztéma képessége a halállomány fenntartására (egyensúlyi halállomány halászat nélkül),

- $\quad$ : halászati koefficiens,

- $\quad p$ : a hal ára,

- $\quad c_{i}$ : halászati költség.

Munro 1979-es eredményeit tekintve elmondható, hogy a játék felírása és megoldása lényegesen egyszerűsíthető az átruházható hasznosság fogalmának bevezetésével. A szerző későbbi munkáiban $[9,10]$ a kooperatív megállapodások megkötésének lehetôségét vizsgálja a halászati kérdések vonatkozásában a Clark modell segítségével. Bemutatja, hogy az EEZ-ken belül mozgó halállományok esetében a közös területi alapon meghatározott halászati jogok nem jól definiáltak, így joggal merülhet fel a potyautas és a „szabályozásnak nem megfelelő” játékosok kérdése a kooperatív megállapodásokhoz kapcsolódóan. Potyautasnak tekinti mindazon játékosokat, akik kihasználják a kooperáló játékosok által elért eredményeket, azonban a kooperációhoz nem csatlakoznak. Nem megfelelés esetén bizonyos kooperáló játékosok szándákosan sértik meg a kooperatív megállapodásban foglalt feltételeket, vállalásokat, előírásokat.

Munro 2007-es cikkében egy kétszemélyes játékot vizsgál, melyben a játékosok csak a halászati költség paramétereikben különböznek. A szerző a játékot kétféle szcenárióban vizsgálja: az első esetben mindkét játékos kifizetése csak a saját aktivitásától függ; a második helyzetben mindkét játékos figyelembe veszi a másik játékos tevékenységét is, melynek eredményeként a hatékonyabb (alacsonyabb költségek mellett operáló) játékos kivásárolja a másikat a halászati kvótájából (azaz egyedül ő halászik) és az elért teljes eredményt 50-50\%-ban osztják el.

Számos szerző [9,10,11,12] felismeri, hogy az exkluzív gazdasági zónák között vándorló halállományok kezeléséhez kapcsolódó egyezményeket ugyan érintheti a potyautas problémája, azonban tapasztalatokon alapuló, gyakorlati probléma nehezen definiálható ezekre az esetekre vonatkozóan.

A nem megfelelés kérdésköréhez kapcsolódóan azt lehet mondani, hogy a kooperatív egyezmények történetében kétségtelenül előfordult és a későbbiekben is előfordulhat ilyen jelenség, azonban a potenciális csalók az egyezményekben foglaltak alapján jogilag is felelősségre vonhatók, hiszen a megállapodók az egyezmény aláírásával jogi kötelezettséget is vállalnak annak betartására. A jogi kötelezettségek egzakt megfogalmazása és betartathatósága egy másik kérdéskör részét képezheti a kutatások során.

A halászati egyezmények vizsgálatára széles körben elterjedt a kétlépcsős játékok alkalmazása [13]. A kétlépcsős játékok esetében az első lépésben történik a koalícióformálás, azaz a játékosok döntenek a regionális halászati gazdálkodási szervezethez vagy egyezményhez való csatlakozásról. A csatlakozók koalíciót alkotnak, a kívülállók szingleton, egyszemélyes koalícióként viselkednek.

Ezt követően a második lépcsőben történik az egyensúlyi halászandó állományok és az egyensúlyi kifizetések meghatározása. Minden koalíció a saját kifizetését maximalizáló stratégiát választja, miközben a többiek viselkedését adottnak feltételezi. 
A játékelméleti kutatásokban kiemelt figyelmet szükséges fordítani a stabilitás kérdésére is. Pintassilgo és Lindroos cikkükben a halászati megállapodások esetében definiált játékokat vizsgálták stabilitási szempontok figyelembe vételével [12]. Egy koalíciót önmagában stabilnak tekintenek, ha egyetlen játékosnak sem érdeke kilépni a koalícióból és szingletonként viselkedni, a többi koalíció változatlansága mellett (ezt azt jelenti, hogy senkinek sem érdeke kilépni az RFMO-ból és potyautasként viselkedni).

Eredményeik alapján ahhoz, hogy egy koalíciós struktúra ne legyen stabil, elégséges feltétel, hogy a szingleton koalíciók kifizetéseinek összeg - ami az egyes koalícióktól való egyoldalú eltérésből adódik - meghaladja a koalíció értékét. A szerzők megmutatták, hogy 2 játékos esetén mind a nagykoalíció, mind a szingletonokból álló koalíciós struktúra stabil, míg $\mathrm{N}>2$ esetében csak a szingletonokból álló koalíciós struktúra lehet stabil. Pintassilgo és munkatársai eredményei alapján elmondható továbbá, hogy minél több szereplős a játék, annál nagyobb a relatív nyereség a teljes kooperációból, ugyanakkor annál alacsonyabb a valószínűsége annak, hogy a megalakult regionális halászati gazdálkodási szervezet stabil lesz [13].

Az előzőekben jellemzően olyan esetekhez kapcsolódó eredményeket mutattunk be, melyek az exkluzív gazdasági zónák között vándorló halállományok esetére korlátozódtak.

A nyílt vizeken és az EEZ-kben egyaránt előforduló halállományokhoz kapcsolódó játékelméleti kutatások az elemzések külön csoportját alkotják, hiszen a játékban több és eltérő tulajdonságú szereplő is érintett, illetve az EEZ-k között vándorló állományokhoz kapcsolódó esettől eltérően a játékosok száma és jellege (természete) időben változik, hiszen az RFMO-k tagjai lehetnek szárazföldi halászó országok is.

Ezen halállományok kezeléséhez kapcsolódó kérdések megoldását és kezelését nehezíti az új belépők problémája, azaz annak a következménye, hogy RFMO-kba újonnan belépők a már a korábban csatlakozott tagok költségeit nem viselik. Ebből adódóan, annak ellenére, hogy a nyílt vizek is az RFMO-k ellenőrzése alá tartoznak, nehéz megkülönböztetni, hogy mi tekinthető illegális és nem szabályozott halászatnak. Nem szabályozott halászati kérdésnek tekinthető például az az eset, amikor egy nem RFMO tag megjelenik a nyílt vizeken és halászati tevékenységbe kezd előzetes engedély nélkül.

A közelmúltban folytatott kutatások esetében egyre elterjedtebb a partíciós függvénnyel adott játékok alkalmazása a nyílt vizek és EEZ-k között vándorló halállományok kezeléséhez kapcsolódó problémákban. A legfőbb előnye ennek a megközelítésnek abban rejlik, hogy a partíciós függvény segítségével megragadhatóvá válnak a megjelenő externáliák és azok hatásai a játékra. Érdemes hangsúlyozni, hogy a partíciós függvénnyel adott játékok alkalmazása nem tekinthető újkeletűnek, hiszen számos empirikus eredményt találhatunk a szakirodalomban, jellemzően, károsanyag kibocsátáshoz és közjavak megóvásához kapcsolódó problémakörökben. A partíciós függvénnyel adott játékok esetében egy játékos kifizetését egy partíciós függvény határozza meg, amely értéke nem csak attól a koalíciótól függ, amihez a játékos csatlakozott, hanem az összes többi koalíciótól egyaránt.

Pintassilgo és szerzőtársai kétlépcsős partíciós függvénnyel adott játékok segítségével vizsgálják az RFMO-k sikeréhez és stabilitásához kapcsolódó kérdéseket a Gordon-Schaefer modell segítségével. A játék első lépcsőjében a játékosok a RFMO partícióinak meghatározásáról 
döntenek, míg a második lépésben kerül kiválasztásra a játékosok gazdasági stratégiája, valamint a halászati erőfeszítés [12,13].

A szerzők legfontosabb eredményei az RFMO-k stabilitásához kapcsolódnak: 1) minél több ország versenyezik a halállományért, annál nagyobb a kooperációból származó várható relatív nyereség értéke, ugyanakkor annal alacsonyabb az RFMO stabilitásának valószínűsége; 2) az új belépők ösztönzik az RFMO-tagokat, hogy kilépjenek az együttmúködésből és gátolják (csökkentik az ösztönzőket) a nem-tagokat a csatlakozásban; 3) az RFMO sikere pozitívan korrelál a költség aszimmetria mértékével, és negatív az RFMO általános szinten vett hatékonyságával.

Ebben a fejezetben számos, a halállományok kezeléséhez kapcsolódó probléma lehetséges játékelméleti kezelését tekintettük át. A probléma még alaposabb megértése céljából szükséges azonban empirikus példákat is bemutatni, melyeket a következő fejezetben foglalunk össze.

\section{Empirikus példák}

A halászati kérdések játékelméleti vizsgálatára leginkább elterjedt módszertanok áttekintését követően érdemes a nemzetközi szakirodalomból röviden körüljárni néhány empirikus példát is.

A nemzetközileg megosztott halállományok esetében, melyek mind a partmenti, mind a távoli országok érdekkörébe beletartoznak, sok esetben tapasztalhatjuk a halállományok túlzott csökkenését és a túlhalászat megjelenését. A túlhalászat annak eredményeként alakul ki, hogy az országok között nem valósult meg együttmúködés.

Példaként tekintsünk egy fogolydilemma helyzetet Ausztrália és Új-Zéland között a narancs tükörhal halászatára vonatkozóan. A narancs tükörhal esetében mindkét fél (Ausztrália és ÚjZéland) részéről egyezménysértés történt (először Ausztrália, majd Új-Zéland), így a kívánt hatás elmaradt. A helyzetet tovább súlyosbította Dél-Afrika belépésével a potyautas megjelenése is. 1998 és 2000 között a narancs tükörhal túlhalászottá vált, hiszen az érintett feleknek nem sikerült időben kooperatív megállapodást kötni.

A kooperatív megoldások „tartósságának” időbeli vizsgálatára példa a Norwegian Spring Spawning Herring esete, mely a legnagyobb halállomány volt az Észak Atlanti térségben. A faj egészséges állapotban Norvégia és Izland között vándorol, azonban az 1970-es években csökkent az állomány, így annak megóvása érdekében a halászatában érdekelt országok halászati moratóriumot vezettek be. Az állomány az 1990-es évekre normalizálódott, ugyanakkor a túlhalászatnak való kitettsége továbbra sem csökkent, így szükségessé vált újabb nemzetközi megállapodások megkötése is. A norvég hering esetében kötött egyezmény a halászat allokációján és az állományok területi eloszlásán alapult, azaz azon, hogy az állomány mekkora mennyiségben és mennyi ideig tartózkodik az érintett felekhez tartozó zónákban. A megállapodás keretében Norvégia és Oroszország: koalcióba lépett, azonban váratlan változások következtek be a halállomány migrációs mintáiban, így a koalíció részesedése csökkenni kezdett, mely szükségessé tette a kooperáció felülvizsgálatát és helyreállítását. Az újratárgyalási folyamat nem ment zökkenőmentesen, hiszen a játékosok egyoldalúan megemelték a kvótáikat, így fogolydilemma helyzet látszott kialakulni. Összességében kvótacserékkel és kvóta átcsoportosítással sikerült a kialakult helyzetet stabilizálni. 


\section{Összefoglalás}

Cikkünk alapvető célja az volt, hogy áttekintsük a nemzetközi halászathoz kapcsolódó legfontosabb kérdéseket és a problémák megoldása során alkalmazott játékelméleti modelleket. Láthattuk, hogy a halászati megállapodások, és így a vizek erőforrásainak védelme napjainkban kiemelt jelentőséggel bír az Európai Unió törekvései között is. A halállomány fenntarthatóságának és a vizek védelmének érdekében számos különböző típusú halászati megállapodást kötnek, melyek célja azonosnak tekinthető, azonban a sikerességük a mai napig - a klímaváltozáshoz kapcsolódó egyezményekhez hasonlóan - számos ponton megkérdőjelezhető.

A játékelmélet módszertani keretrendszeréből adódóan számos lehetőséget nyújt az előzőekben nevesített megállapodások és azok következményeinek elemzésére és vizsgálatára, melyek relevanciája megkérdőjelezhetetlen. Az egyezmények stabilitása tekintetében elmondható, hogy a stabilitás a csatlakozók létszámának növekedésével csökken, mely vonzóvá teheti a potyautassá válást. Egyezmények nélkül azonban fogolydilemma helyzettel állunk szemben, mely még inkább megnehezíti a probléma kezelését.

Későbbi kutatások során a nyílt vizek esetében szükséges lehet a nem szabályozott halászatból adódó túlhalászat, illetve a potyautas jelenség potenciális elkerülési vagy csökkentési lehetőségének számbavétele is.

\section{Hivatkozások}

[1] Karnai, L., Szűcs, I. (2018): Outlooks and perspectives of the Common Carp production. Annals of The Polish Association of Agricultural and Agribusiness Economists XX.: 1, p. 6472.

[2] Pintér, T. (2012): Duna-stratégia - fejlesztési kilátások és ellentmondások. In: Róbert, P. (ed.) Magyarország társadalmi- gazdasági helyzete a 21. század első évtizedeiben: A 2011. június 15.-i Kautz Gyula Emlékkonferencia válogatott tanulmányai. Széchenyi István Egyetem, Győr pp 223-234

[3] Harangozó, G., Zilahy, G. (2015): Cooperation between business and non-governmental organizations to promote sustainable development. Journal of Cleaner Production, 89, 1831.

[4] Munro, G. R. (1979): The Optimal Management of Transboundary Renewable Resources. Canadian Journal of Economics, 12: 355-376

[5] Schaefer M. B. (1954): Some aspects of the dynamics of populations important to the management of commercial marine fisheries. Inter-American Tropical Tuna Commission Bulletin 1:25-56

[6] Schaefer M. (1991): Some aspects of the dynamics of populations important to the management of the commercial marine fisheries. Bulletin of Mathematical Biology Volume 53, Issues 1-2, pp 253-279 
[7] Clark C. W., Munro G. R. (1975): The economics of fishing and modern capital theory: A simplified approach. Journal of Environmental Economics and Management, 2, issue 2, p. 92-106.

[8] Clark C. W. (1980): Restricted Access to Common Property Fisheries Resources: A GameTheoretic Analysis. In: P.Liu (ed.): Dynamic Optimization and Mathematical Economics. New York: Plenem Press.

[9] Munro, G. R. (2007): Internationally Shared Fish Stocks, the High Seas, and Property Rights in Fisheries. Marine Resource Economics Vol. 22, No. 4 (2007), pp. 425-443

[10] Munro, G. M. (2008): Game theory and the development of resource management policy: The case of international fisheries. Game Theory and Policy Making in Natural Resources and the Environment. 12-41.

[11] Pintassilgo P. (2003): A coalition approach to the management of high seas fisheries in the presence of externalities. Natural Resource Modeling 16(2):175-197

[12] Pintassilgo P., Lindroos M. (2008): Coalition formation in straddling stock fisheries: A partition function form approach. International Game Theory Review 10(3):303--317

[13] Pintassilgo P., Finus M., Lindroos M., Munro G. R. (2010): Stability and success of regional fisheries management organizations. Environmental and Resource Economics 46(3):377-402 